\title{
Democratization
}

\section{Local determinants of an emerging electoral hegemony: the case of Justice and Development Party (AKP) in Turkey}

\section{Kursat Cinar}

To cite this article: Kursat Cinar (2016) Local determinants of an emerging electoral hegemony: the case of Justice and Development Party (AKP) in Turkey, Democratization, 23:7, 1216-1235, DOI: $10.1080 / 13510347.2015 .1077228$

To link to this article: https://doi.org/10.1080/13510347.2015.1077228

Published online: 17 Sep 2015.

Submit your article to this journal \lceil

Џ Article views: 618

Q View related articles $\sqsubset$

View Crossmark data ¿

Citing articles: 7 View citing articles $\longleftarrow$ 


\title{
Local determinants of an emerging electoral hegemony: the case of Justice and Development Party (AKP) in Turkey
}

\author{
Kursat Cinar \\ Department of Political Science, Bilkent University, Ankara, Turkey
}

\begin{abstract}
"Party hegemony" is a macro-level characteristic of party systems, which is a product of persistent and overwhelming electoral victories that leads to domination of the parliamentary system by a single party. Party hegemony can only emerge through a collection of individual-level (albeit aggregated), lower-level structural, and macrolevel institutional factors. This article intends to shed light on hegemonic party systems by incorporating all of these aspects. It analyses the case of the Justice and Development Party (AKP) in Turkey as a hegemonic party in the making. Based on individual-level survey data as well as an original province-level dataset, the article examines the role of ideology, pork barrel politics, economic voting, demographics, and political institutions in AKP's rising hegemony. The replicable nature of the dataset enables further testing of these findings in comparable cases for generalizability.
\end{abstract}

\section{ARTICLE HISTORY Received 3 January 2015; Accepted 9 July 2015}

KEYWORDS hegemonic party; Justice and Development Party (AKP); Turkey; local politics; ideology; pork barrel politics; economic voting; political institutions; electoral disproportionality

\section{Introduction}

The problem of today's non-consolidated democracies is usually not their total downfall or breakdown, but their incremental decay and erosion over time. ${ }^{1}$ Within the context of the "decay of democracy", hegemonic parties emerge by ensuring success at the ballot box over consecutive elections in multi-party settings, yet ruling in semi-authoritarian conditions. As of today, there are more than 30 hegemonic parties throughout the world, including the National Front in Malaysia, People's Action Party in Singapore, and Zimbabwe African National Union-Patriotic Front (ZANU-PF) in Zimbabwe.

I classify a party as "hegemonic" if it fulfils five criteria: (1) it should be hegemonic in number, winning a larger number of seats than its opponents; (2) it should enjoy a hegemonic bargaining position within the party system it operates; (3) it should be hegemonic chronologically, that is, it should be the governing party over a substantial period of time, not only for a few years; (4) it should have governmental hegemony through "a series of interrelated and mutually supportive public policies that give particular shape to the national political agenda"; ${ }^{2}$ and (5) it should have clear authoritarian tendencies. Hegemonic party systems are different from "uncommon democracies", ${ }^{3}$ also 
known as "predominant party systems"4 that are governed by one political party for prolonged periods under democratic conditions - for example, once observed in Sweden (Social Democrats), Japan (Liberal Democrats), and Italy (Christian Democrats). There are significant authoritarian traits in hegemonic party regimes that distinguish them from these regimes. ${ }^{5}$

There are many valuable studies on the survival or demise of hegemonic parties. ${ }^{6}$ Yet, these studies fail to address why these parties emerge in the first place. In an exceptional study, Bader focuses on two major mechanisms behind the rise of hegemonic parties, that is, patronage and intimidation of the opposition. ${ }^{7}$ While these mechanisms are valuable for understanding hegemony building, limiting the emergence of hegemonic parties to these two mechanisms leaves important theoretical grounds unaddressed. Furthermore, the extant body of literature on hegemonic parties focuses mostly on nation-wide structural and institutional factors that explain either the success or failure of hegemonic parties. In addition to these systemic structural and institutional conditions at the national level, hegemonic parties burgeon and succeed in certain socioeconomic and demographic conditions at the sub-systemic level. As Trounstine succinctly remarks, the local level is the source of numerous political outcomes that matter because they represent a large proportion of political events. ${ }^{8}$ In a similar vein, Gibson and Suarez-Cao maintain that conceiving party systems only at the national level leads to "conceptual and measurement incompleteness in the study of party systems". ${ }^{9}$ This article aims to contribute to the political parties literature, by offering a sub-systemic, local-level analysis on an emerging hegemonic party, that is, Justice and Development (AKP) in Turkey.

Since its establishment in 2001, AKP has ruled Turkey by securing consecutive electoral victories with comfortable margins. Having roots in previous Islamist parties in Turkey, AKP first differentiated itself from its predecessors by presenting itself as a moderate "religiously conservative party" like the denominational parties in Europe, which ensured the party political support from different parts of the political spectrum and political success in its formative years. ${ }^{10}$ Rallying most of the right-wing voters (and even initially some leftists) thanks to its promises of economic expansion and affluence, Turkey's long-awaited admission to the EU, and more integration into global markets, AKP also attracted the attention of many international observers. Some even envisioned the party as a "model" in the volatile political atmosphere in the Middle East. However, enthusiasm of domestic and international observers has faded as AKP has drifted away from its European aspirations and Western liberal conceptualization of democracy to more illiberal and electoralist notions.

It is true that AKP's earlier period was characterized by moderation, which brought about the party political mass support. However, as the party grew stronger and took a firm grip on Turkish politics (especially after the 2010 Constitutional Referendum), it has transitioned from accommodative to more conflictual behaviour and policies. AKP has clearly politicized its polarizing rhetoric to take advantage of the salient religioussecular cleavage in Turkey, contrary to the expectations of the scholars who anticipate moderation and inclusiveness on the side of the ruling party. ${ }^{11}$ AKP has started to show authoritarian tendencies especially in recent years. In 2012, when talking about the checks and balances in Turkey, the AKP leader (now the President) Recep Tayyip Erdoğan stated that "the thing called separation of powers stands as an impediment in front of us". ${ }^{12}$ As of today, AKP operates as a "proto-hegemonic religious party". ${ }^{13}$ Far from being tolerant and pluralistic, as is the case for denominational parties in 
Europe, AKP is "proto-hegemonic", since it is "semi-loyal to democratic norms and institutions". ${ }^{14}$ Erdoğan states that Turkish society ("new Turkey", as he likes to put it) should raise religiously devout (dindar) generations, disregarding the diversity of Turkish society. In a similar vein, Sadık Yakut, AKP's Kayseri MP and the ViceChair of the Parliament, stated: "I think that mixed-gender education is a great mistake, a mistake that is to be corrected in the near future". ${ }^{15}$ In line with these statements, the National Education Council (Milli Eğitim Şurası), the highest advisory agency to the Ministry of Education, submitted a proposal for law enactment to the Parliament during its nineteenth meeting on 2-6 December 2014. The proposal included compulsory religion courses for all of the first, second, and third graders in primary schools (aged 6-8). These statements and policy measures reflect AKP's increasingly authoritarian tone, which leaves little or no room for a pluralistic, democratic society.

There are also serious concerns about press freedom, freedom of expression, and academic freedom in Turkey. For instance, Freedom House downgraded Turkey's press freedom rating from "partly free" to "not free" in 2014. Ranking Turkey $154^{\text {th }}$ (among 180 countries) in 2014, Reporters without Borders further pinpoint problems about the freedom of expression in Turkey, underlining the issues of jailed journalists (the highest in the world, even ahead of Iran and China) and self-censorship. Liberal elements of the AKP's once broad-based coalition have been sidelined and marginalized; military tutelage and the dominance of secular state elites have been replaced by over-concentration of power at the new centre of Turkish politics due to the plebiscitarian nature of the AKP rule and lack of proper checks and balances. ${ }^{16}$ In Özbudun's words, AKP era can be best characterized with a "drift towards an excessively majoritarian conception of democracy, or even an electoral authoritarianism of a more markedly Islamic character". ${ }^{17}$

Yet, AKP continues to garner the political support of approximately half of the Turkish electorate. As Müftüler-Baç and Keyman suggest, "the AKP has made it clear that it is firmly at the top of the political pyramid, and that its opponents have yet to find any realistic route to removing it". ${ }^{18}$ What makes many experts and scholars so sure that AKP is here to rule Turkey for extended periods? What drives the electoral support for this increasingly authoritarian, hegemony-aspiring party? This article aims to provide answers to these questions by offering the local-level determinants of the AKP support in light of an original dataset.

The structure of this article is as follows. The first section presents a brief overview of the AKP electorate. The second section lays out the theoretical expectations and hypotheses of this study, regarding the role of ideology, economic voting, demographics, and political institutions on the rise of hegemonic parties. The third section presents the research design. This section sets forth several measures and several longitudinal and cross-sectional regression analyses (ordinary least squares (OLS) and ordered logit analyses) to robustly measure party hegemony. The fourth section provides the empirical findings of the research. The fifth section concludes.

\section{A brief overview of the AKP electorate}

Despite some interventions due to military coups, Turkey has a tradition of free and fair democratic elections dating back to 1950 . However, dearth of systematic data collection at the individual level until recent years and weak influence of the behaviourist approach to Turkish politics hamper clear-cut analyses of party electorates. ${ }^{19}$ To 


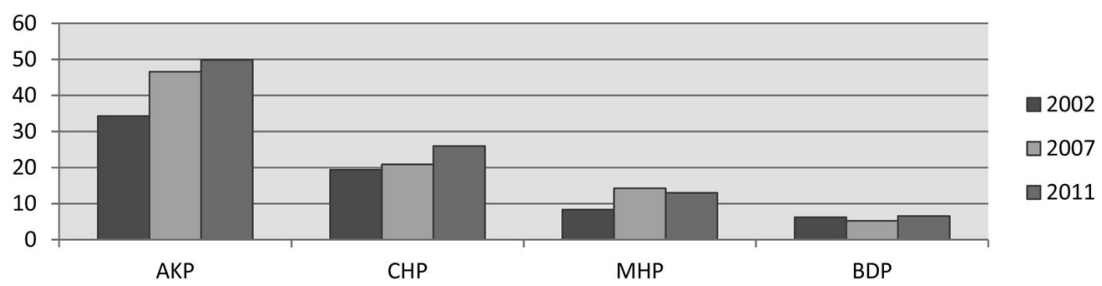

Figure 1. National elections during the AKP governments. Note: Vote share trends of the four major parties in Turkey: religious conservative Justice and Development Party (AKP), secular Republican People's Party (CHP), Nationalist Action Party (MHP), and pro-Kurdish Peace and Democracy Party (BDP). For the sake of brevity, the predecessors of the BDP (Democratic People's Party and Democratic Society Party), which were banned by Constitutional Court are also shown under pro-Kurdish vote as these successive parties are clearly a continuation of each other institutionally. Source: Turkish Electoral Council (YSK).

address this problem, this research starts with a brief overview of the party constituency under analysis, that is, AKP voters.

AKP succeeds to garner an increasing percentage of vote shares over successive national elections. Figure 1 shows the vote share trends of four major parties in Turkey in 2002, 2007, and 2011 elections. AKP's vote share has clearly and consistently risen over these elections, reaching $49.8 \%$ in the 2011 national election. In other words, half of the Turkish electorate cast their ballots for the governing party.

This article delves into to the emerging AKP hegemony at the local level. However, it is vital to support this level of analysis with an individual-level analysis so as to offer a complete portrayal of this political phenomenon. Hence, before presenting my own results, I refer to a recent survey by an independent Turkish research and consultancy firm, KONDA, to provide the main characteristics of the AKP voters. Why do people support the AKP in the first place? What are their major drivers? According to the KONDA survey, there are four main reasons why voters opt for the AKP: $41 \%$ of the AKP voters claim that they support the party because of its "successful public services", $25 \%$ for "economic and political stability", $14 \%$ for "ideology", and $12 \%$ for "the party leadership". ${ }^{20}$

Furthermore, AKP gathers more votes from the conservative parts of the society. According to the survey, $63 \%$ of the voters who identify themselves as "religiously conservative" support the AKP, whereas only $7 \%$ and $11 \%$ of this electorate choose to vote for the Republican People's Party (CHP) and the Nationalist Action Party (MHP), respectively. These differences show how AKP successfully differentiates itself from other major parties (even ideologically closer ones, such as the $\mathrm{MHP}^{21}$ ) to mobilize and politicize more conservative sections of the society. As Çarkoğlu remarks, "the pro-Islamist electoral tradition forms the intellectual and organizational backbone of the AKP". ${ }^{22}$

Among the electorate of each major political party in Turkey, the young (aged 1828 ) represent $21 \%, 24 \%, 33 \%$, and $40 \%$ of all AKP, CHP, MHP, and BDP (Peace and Democracy Party) voters, respectively. In other words, younger generations characterize the pro-Kurdish BDP vote and the nationalist MHP vote more substantively, whereas they are below the national average (25\%) in the AKP constituency (21\%). This is understandable, given the fact that the growing authoritarian tone of AKP governance has drawn the biggest negative reaction from young people, as evidenced by the Gezi Park protests in 2013. Furthermore, the unemployment rate is the highest among 
the young, $20.4 \%$ as compared to $10 \%$ (the overall unemployment rate). ${ }^{23}$ Compared to older generations, the AKP fails to garner the same level of support from younger voters.

The relationship between voters' educational attainment and party preferences is also very interesting. Voters with lower than secondary education constitute $67 \%$ and $71 \%$ of the AKP and the pro-Kurdish BDP electorate, respectively. ${ }^{24}$ In other words, both the AKP and the BDP attract less educated voters. On the other hand, $22 \%$ and $18 \%$ of leftist CHP and right-wing MHP voters hold university degrees and higher, whereas this figure is only $10 \%$ for the AKP voters.

There are many insights from individual-level analysis of the Turkish electorate into the emerging AKP hegemony. As this section suggests, the AKP gathers more votes from the conservative, older, and less educated sections of the society. These findings are yet to be supported with more in-depth, local-level analysis. The following section lays out the theoretical foundations of this analysis.

\section{Theoretical expectations/hypotheses}

There are various motivations why voters support political parties. The previous section has already provided an overview of the Turkish electorate at the individual level. But, there is more to be seen through a local-level analysis. Before delving into the empirical side of the story, let us lay out the theoretical expectations and hypotheses of this study. Overall, I examine the role of ideology, economic voting, demographics, and political institutions on the rise of hegemonic parties.

Some scholars of the political behaviourist literature assert that voters side with the parties that are ideologically closest to themselves. ${ }^{25}$ Hegemonic parties usually aspire to be "over-sized coalitions", ${ }^{26}$ aiming to attract a substantial portion (at least more than half) of the whole society. To this end, they may choose to play the card of ideology in societies where left-right cleavage is pivotal or they may opt for a catch-all strategy to win the masses in countries with lower ideological divides. Hence, we should first analyse the social dynamics of the country in which the hegemonic party operates to understand either of which strategy it would pursue.

In the case of Turkish politics, the secular-religious divide has been salient since the establishment of the Turkish Republic. The state elites' attempt to establish a secular nation-state has clashed with the religious conservatism of the devout electorate in the periphery. Right-wing parties, particularly the Islamist parties, have rallied the latter group for electoral support. Indeed, one of the major drivers of the AKP's electoral success is its ability to mobilize religious conservative voters. As Keyman and Gümüşçü argue, "religion has always remained omnipresent in Turkish society as a dominant ideology". ${ }^{27}$ Many right-wing parties have utilized religion as one of the main anchors in political debates and competition in Turkish politics. Like their counterparts throughout the Middle East, Islamist parties in Turkey started to strengthen in the 1970s with promises of economic prosperity and replacement of extant political structures and social practices with those viewed as more in line with core religious values. ${ }^{28}$

AKP is the religiously conservative party par excellence in Turkey that has moved Islamist parties from the fringe of political competition into the limelight by turning into a system-oriented party with strong financial and organizational backing. As the previous section suggests, religiously conservative sections of the society have acted as the backbone of the party support. At the local level, Central and Eastern Anatolian 
and Black Sea regions have been the strongholds of the party, ${ }^{29}$ thanks to the overwhelmingly pious electorate in these regions. I expect to see a positive correlation between religiosity and AKP's emerging hegemony at the local level.

H1: There is a strong positive relationship between religiosity and the AKP's support at the local level. Provinces with higher religiosity should yield higher AKP support and higher chances of AKP hegemony.

"Politics of vote buying" is certainly at the heart of hegemonic party support. ${ }^{30}$ For instance, Golkar under the leadership of Suharto (1966-1998) dominated Indonesian politics as the hegemonic party through its electoral machine at the local level, ${ }^{31}$ utilizing the "tragic brilliance" 32 of providing rewards for loyal localities and punishing mavericks. As Garner and Garner maintain, a hegemony-aspiring party "must diffuse its presence throughout all the reaches of the state". ${ }^{33}$ To this end, provision of basic public goods can be vital for the hegemonic party support. Due to the political logic of pork barrel politics, ${ }^{34}$ localities with better provision of public goods, such as infrastructure, are expected to be more inclined to continue their support for the governing party. In the Turkish case, it has already been discussed that $41 \%$ of the AKP voters underline the importance of the AKP's "successful public services". Overall, in light of the extant literature on hegemonic parties and the qualitative evidence for the AKP government, I expect that:

$\mathrm{H} 2$ : There should be strong positive correlation between the provision of basic public goods and services and the electoral support for the hegemonic party.

As Kitschelt and Wilkinson argue, "voters hold incumbents accountable for their performance during the electoral term, based upon their effort and performance". ${ }^{35}$ Hence, as voters reward the governing party for better services, they can also be inclined to punish governments for bad economic outcomes. To this end, economic stature of a locality can affect the odds of success for the governing parties. Reuter and Gandhi maintain that deteriorating economic conditions can strengthen coalitions against hegemonic parties to challenge them in elections. ${ }^{36}$ If economic conditions deteriorate at the local level, this should adversely affect the electoral success of hegemonic parties.

H3: Poor economic performance at the local level hinders the political prospects of hegemonic parties.

Besides ideology, pork barrel politics, and economic voting, locality-specific factors can also influence the support level for hegemonic parties. Demographic attributes of subnational units, such as median age, net migration, and urbanization, affect the level of support for political parties. ${ }^{37}$ The theory of political generations asserts that enduring and relevant political consequences result from critical experiences during the formative years of the electorate. ${ }^{38}$ Poorer localities with higher rates of outmigration are likely to depend more on clientelistic goods and less on programmatic ones than more affluent localities. ${ }^{39}$ Newly urbanizing peripheral areas can be a boon for populist parties ${ }^{40}$ and so on. All in all, local-level demographic factors should be taken into account to determine the level of electoral support for political parties, including the hegemonic ones. Thus, I incorporate these demographic dynamics into my analysis of the rising AKP hegemony in Turkey.

Citizen-politician relations are also contingent upon electoral institutions. ${ }^{41}$ Carey and Hix state that electoral institutions, especially legal thresholds for political parties 


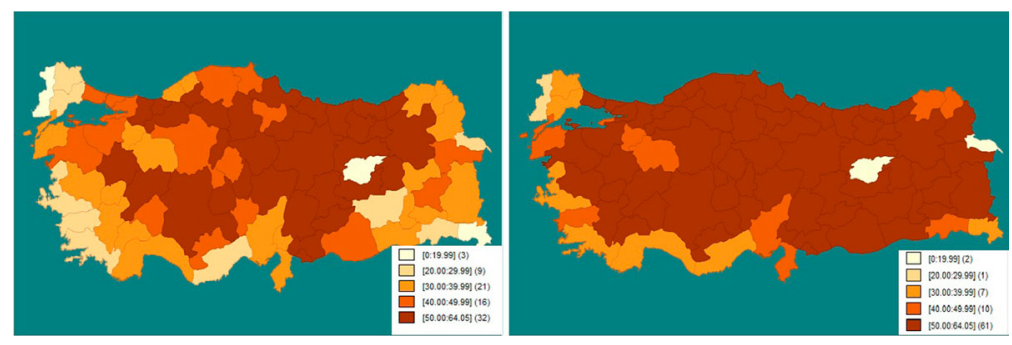

Figure 2. Comparison between average AKP vote shares (left) and seat shares (right). Note: Comparison between average AKP vote and seat shares in 2002, 2007, and 2011 elections. Lighter colours represent lower electoral support whereas darker colours correspond to higher AKP support. Ranges defined (lighter to darker): 1st range: $0-19.99 \%$; 2nd range: $20.00-29.99 \%$; 3rd range: $30.00-39.99 \%$; 4th range: $40.00-49.99 \%$; 5 th range: 50.00 and higher. Source: Turkish Electoral Council (YSK). Data compilation and map creation are done by the author (in GeoDa).

to be represented in parliaments, significantly increase electoral disproportionality. ${ }^{42}$ Turkey has a multi-member proportional representation (PR) system with D'Hondt formula and a $10 \%$ national electoral threshold. Hence, political parties that fail to pass this threshold are not represented in the Parliament. This gives major parties an upper hand in representation. This was particularly evident in the 2002 national election when only one party (Republican People's Party, CHP) along with the AKP passed the $10 \%$ electoral threshold, which helped AKP to almost double its share of seats to $66 \%$, compared to its vote share of $34 \%$. Figure 2 shows the comparison between average AKP vote and seat shares across national elections. The AKP gains very high levels of seats ( $50 \%$ and higher) in the Parliament, even in provinces (for example, those in Southeast Anatolia, inner Aegean) in which it fails to gather high levels of electoral support. Mid-range vote shares (between $30-40 \%$, shown in $3^{\text {rd }}$ range) transform into very high seat shares (50\% and higher, shown in $5^{\text {th }}$ range), whereas even low-to-mid-range vote shares $\left(20-30 \%\right.$, shown in $2^{\text {nd }}$ range) enable the party to gain mid-range and even higher seat shares in the Parliament just because of the $10 \%$ electoral threshold. This comparison clearly shows that electoral institutions, and in this case electoral disproportionality, can heavily influence the outcomes of elections in emerging hegemonic party systems.

In light of Figure 2, I expect that electoral disproportionality should favour the AKP hegemony. The effect of electoral disproportionality should be evident in seat distributions. Hence, I add the "Gallagher index" (1991), the most-widely used indicator for electoral disproportionality, to my regressions. I expect a positive correlation between electoral disproportionality and AKP seat shares.

H4: Electoral institutions may work to the advantage of hegemonic parties. To this end, higher electoral disproportionality should compound electoral hegemonies of these parties.

\section{Research design}

I utilize various province-level electoral measures as dependent variables in my statistical analyses. As my point of reference, I take into account electoral outcomes from all national elections $(2002,2007$, and 2011, to be exact) that the AKP contested in 81 provinces. To understand the local-level sources of the AKP hegemony, four types of 
indicators of electoral hegemony are used in separate statistical analyses. These indicators particularly relate to "hegemony in number" and "chronological hegemony" criteria that I have listed for the classification of a hegemonic party. "Hegemonic bargaining position", "governmental hegemony", and "authoritarian tendencies for hegemony" have also been discussed before.

First, I gather data on the AKP's vote and seat shares in individual national elections. Analyses of the AKP's vote and seat shares in individual elections over time will provide us with important insights regarding the relationship between our explanatory variables (ideology and pork barrel politics) and the AKP's emerging hegemony based on these political factors. Since both of these variables (that is, vote and seat shares) are continuous measures, I conduct OLS-analyses for both of them.

Along with vote and seat shares, I construct two additional variables to fully understand the determinants of the AKP hegemony. First, AKP's electoral victories in each province for each national election are used to create a variable. If the AKP is the first party in a province in an election, then a value of 1 is assigned for that particular province and election (if not, 0 ). Then, values for other elections for the same province are collected with the same technique. Hence, a measure is created for each 81 province (valued between 0 and 3). Formally, this variable (named "AKP Wins" variable) can be shown as:

$$
\mathrm{AKP} \mathrm{Wins}_{j}=\sum_{i j k}
$$

such that

$i$ is 1 if the AKP is the first party in province $j$ in election $k$,

0 if not; where $j=1,2, \ldots, 81$ and $k=2002,2007,2011$.

As the fourth measure for party hegemony, I construct another variable based on the AKP seat shares. To be more specific, if the AKP seat share in a province in a particular election surpasses $50 \%$, then a value of 1 is assigned for that particular locality and election (if not, 0 ). Then, values for remaining elections for the same province are collected with the same technique. Hence, a measure is created for each of the 81 provinces. Formally, this variable (named "AKP Seat 50P") can be shown as:

$$
\operatorname{AKP} \text { Seat } 50 \mathrm{P}_{j}=\sum_{i j k}
$$

such that

$i$ is 1 if the AKP Seat Share exceeds $50 \%$ in province $j$ in election $k$,

0 if not; where $j=1,2, \ldots, 81$ and $k=2002,2007,2011$.

A comparison with the "AKP Wins" and "AKP Seat 50P" can be useful to fully understand both variables. For instance, the AKP was the first party in all of the three national elections in Balıkesir province (thus, the "AKP Wins" is 3 for Balıkesir, that is, $1+1+1=3$ ). On the other hand, the AKP exceeded the $50 \%$ seat threshold in 2002 and 2007 elections in Balıkesir yet it could not surpass it in the 2011 election (hence, the "AKP Seat 50P" is 2 for Balıkesir, that is, $1+1+0=2$ ). Due to the interpretative nature of these variables (that is, score of 3 - and only 3 - refers to hegemony at the local level), I treat them as ordinal variables (though they are seemingly count variables) and, hence, run ordered logit regressions for both of them.

The tabulation of these two ordinal variables with frequency ratios for each value is shown in Table 1 to provide the electoral profile of the 81 provinces during the AKP era. 
Table 1. Tabulation of "AKP Wins" and "AKP Seat 50P" variables.

\begin{tabular}{lcrrr}
\hline & \multicolumn{2}{c}{ AKP Wins } & \multicolumn{2}{c}{ AKP Seat 50P } \\
\cline { 2 - 4 } Value & Frequency & Percent & Frequency & Percent \\
\hline 0 & 11 & 13.58 & 17 & 20.99 \\
1 & 5 & 6.17 & 9 & 11.11 \\
2 & 9 & 11.11 & 8 & 9.88 \\
3 & 56 & 69.14 & 47 & 58.02 \\
Total & 81 & 100.00 & 81 & 100.00 \\
\hline
\end{tabular}

Note: "AKP Wins" is based on the AKP electoral victories in each province in three national elections that the AKP contested. "AKP Seat $50 \mathrm{P}$ " is based on whether the AKP exceeded $50 \%$ seat threshold in each province in three national elections. Source: Turkish Electoral Council (YSK). Data compilation and creation is done by the author.

This table offers us valuable insights into the AKP's electoral success. For instance, AKP succeeded in being the first party in $69 \%$ of all provinces (56 out of 81 ) in all of the three national elections. Likewise, it managed to surpass the $50 \%$ threshold (see "AKP Seat $50 \mathrm{P}$ " variable) in $58 \%$ of all provinces in all elections.

The longitudinal analyses of the AKP's vote and seat shares for individual elections show the dynamic interaction of explanatory variables with the electoral support levels for the AKP over time. Cross-sectional analyses of "AKP Wins" and "AKP Seat 50P" provide us with additional insights about the AKP hegemony (see Appendix 1 for descriptive statistics). The correlation matrix of independent variables shows that there is not a problem of multicollinearity (see Appendix 2). Furthermore, pair-wise comparisons of key variables (regarding ideology and pork barrel politics) with the dependent variables (DV's) are still in the same direction and statistically significant when potentially collinear control variables (such as education, urbanization, net migration) are not included.

\section{Empirical findings}

I conduct longitudinal and cross-sectional analyses of the AKP's rising hegemony based on four types of dependent variables in eight different models. For logit regressions, I execute the Clarify programme by King et al. and simulate 81 real-life observations (both for dependent and independent variables) as 1000 observations (each). ${ }^{43}$ Then, I calculate the impact of the changes of explanatory variables on dependent variables, in light of possible scenarios that can be observed in real life (for example, the effect of local-level unemployment changing from $5 \%$ to $10 \%$ ). Table 2 illustrates my empirical findings.

While the secondary education attainment at the local level has a negative correlation with the dependent variables, the only statistically significant effect of this variable can be found for the AKP Seat variable for the 2002 election. One unit increase in this variable caused a 1.19 unit decrease in AKP seat share during this election. Individual-level (survey) data show a stronger association between educational attainment and AKP support. Aggregated data on education fail to illustrate such a strong link between this indicator and the AKP hegemony.

One of the major explanatory variables in our analysis is linked to religiosity. The indicator for religiosity, that is, preacher school enrolment at the local level, is the strongest explanatory variable in the model (based on the $t$-scores for independent variables). Religiosity is indeed very strongly and positively associated with the AKP support levels. 
Table 2. Political, socioeconomic, and demographic determinants of the AKP's rising hegemony.

\begin{tabular}{|c|c|c|c|c|c|c|c|c|}
\hline $\begin{array}{l}\text { Dependent Variable } \\
\text { Model Estimated }\end{array}$ & $\begin{array}{c}\text { AKP Vote } \\
2002 \\
\text { OLS }\end{array}$ & $\begin{array}{c}\text { AKP Vote } \\
2007 \\
\text { OLS }\end{array}$ & $\begin{array}{c}\text { AKP Vote } \\
2011 \\
\text { OLS }\end{array}$ & $\begin{array}{c}\text { AKP Seat } \\
2002 \\
\text { OLS }\end{array}$ & $\begin{array}{l}\text { AKP Seat } 2007 \\
\text { OLS }\end{array}$ & $\begin{array}{c}\text { AKP Seat } \\
2011 \\
\text { OLS }\end{array}$ & $\begin{array}{c}\text { AKP Wins } \\
\text { Ordered Logit }\end{array}$ & $\begin{array}{l}\text { AKP Seat 50P } \\
\text { Ordered Logit }\end{array}$ \\
\hline Secondary Education & $\begin{array}{c}-0.07 \\
(0.21) \\
{[-0.34]}\end{array}$ & $\begin{array}{c}-0.01 \\
(0.20) \\
{[-0.03]}\end{array}$ & $\begin{array}{c}-0.01 \\
(0.20) \\
{[-0.06]}\end{array}$ & $\begin{array}{c}-1.19 * * * \\
(0.43) \\
{[-2.74]}\end{array}$ & $\begin{array}{c}-0.09 \\
(0.38) \\
{[-0.23]}\end{array}$ & $\begin{array}{c}-0.22 \\
(0.44) \\
{[-0.51]}\end{array}$ & $\begin{array}{c}-0.01 \\
(0.04) \\
{[-0.23]}\end{array}$ & $\begin{array}{c}-0.02 \\
(0.04) \\
{[-0.50]}\end{array}$ \\
\hline Preacher School Enrolment & $\begin{array}{c}14.32^{* * *} \\
(3.37) \\
{[4.25]}\end{array}$ & $\begin{array}{c}15.84^{* * *} \\
(3.01) \\
{[5.26]}\end{array}$ & $\begin{array}{c}17.56^{* * *} \\
(3.20) \\
{[5.48]}\end{array}$ & $\begin{array}{c}22.49 * * * \\
(6.05) \\
{[3.72]}\end{array}$ & $\begin{array}{c}24.89 * * * \\
(4.91) \\
{[5.06]}\end{array}$ & $\begin{array}{c}27.43^{* * *} \\
(5.17) \\
{[5.30]}\end{array}$ & $\begin{array}{c}2.72^{* * *} \\
(0.98) \\
{[2.77]}\end{array}$ & $\begin{array}{c}2.70^{* * *} \\
(0.85) \\
{[3.17]}\end{array}$ \\
\hline Basic Health Services & $\begin{array}{c}-0.01 \\
(0.45) \\
{[-0.01]}\end{array}$ & $\begin{array}{c}-0.05 \\
(0.36) \\
{[-0.16]}\end{array}$ & $\begin{array}{l}0.03 \\
(0.37) \\
{[0.10]}\end{array}$ & $\begin{array}{l}0.49 \\
(0.76) \\
{[0.65]}\end{array}$ & $\begin{array}{l}0.22 \\
(0.66) \\
{[0.35]}\end{array}$ & $\begin{array}{c}-0.17 \\
(0.61) \\
{[-0.28]}\end{array}$ & $\begin{array}{c}-0.06 \\
(0.09) \\
{[-0.71]}\end{array}$ & $\begin{array}{c}-0.00 \\
(0.07) \\
{[-0.06]}\end{array}$ \\
\hline Basic Infrastructure Services & $\begin{array}{l}0.16^{*} \\
(0.09) \\
{[1.74]}\end{array}$ & $\begin{array}{c}0.21 * * * \\
(0.09) \\
{[2.41]}\end{array}$ & $\begin{array}{c}0.24^{* * *} \\
(0.10) \\
{[2.59]}\end{array}$ & $\begin{array}{l}0.38^{*} \\
(0.20) \\
{[1.89]}\end{array}$ & $\begin{array}{l}0.25 \\
(0.16) \\
{[1.51]}\end{array}$ & $\begin{array}{l}0.37^{*} \\
(0.22) \\
{[1.67]}\end{array}$ & $\begin{array}{l}0.05^{* *} \\
(0.02) \\
{[2.13]}\end{array}$ & $\begin{array}{l}0.02 \\
(0.02) \\
{[1.02]}\end{array}$ \\
\hline Unemployment & $\begin{array}{c}-1.04 \\
(0.66) \\
{[-1.57]}\end{array}$ & $\begin{array}{c}-1.83^{* * *} \\
(0.60) \\
{[-3.04]}\end{array}$ & $\begin{array}{c}-1.83^{* * *} \\
(0.64) \\
{[-2.85]}\end{array}$ & $\begin{array}{l}0.81 \\
(1.35) \\
{[0.60]}\end{array}$ & $\begin{array}{c}-2.79 * * * \\
(0.91) \\
{[-3.07]}\end{array}$ & $\begin{array}{c}-2.85^{* * *} \\
(1.33) \\
{[-2.15]}\end{array}$ & $\begin{array}{c}-0.32^{* *} \\
(0.16) \\
{[-1.94]}\end{array}$ & $\begin{array}{c}-0.19 \\
(0.13) \\
{[-1.45]}\end{array}$ \\
\hline Pop.n out of Social Security & $\begin{array}{c}-0.87^{*} \\
(0.49) \\
{[-1.78]}\end{array}$ & $\begin{array}{c}-0.79 * \\
(0.48) \\
{[-1.65]}\end{array}$ & $\begin{array}{c}-0.90^{* *} \\
(0.46) \\
{[-1.97]}\end{array}$ & $\begin{array}{c}-1.57 \\
(0.98) \\
{[-1.59]}\end{array}$ & $\begin{array}{c}-1.60^{*} \\
(0.92) \\
{[-1.73]}\end{array}$ & $\begin{array}{c}-1.85^{* *} \\
(0.89) \\
{[-2.08]}\end{array}$ & $\begin{array}{c}-0.16 \\
(0.13) \\
{[-1.21]}\end{array}$ & $\begin{array}{c}-0.06 \\
(0.10) \\
{[-0.59]}\end{array}$ \\
\hline $\begin{array}{l}\text { Median Age } \\
\text { Model Estimated } \\
\end{array}$ & $\begin{array}{l}0.52 \\
(0.35) \\
{[1.47]} \\
\text { OLS } \\
\end{array}$ & $\begin{array}{c}-0.85^{* * *} \\
(0.31) \\
{[-2.75]} \\
\text { OLS } \\
\end{array}$ & $\begin{array}{c}-0.11 \\
(0.31) \\
{[-0.37]} \\
\text { OLS } \\
\end{array}$ & $\begin{array}{l}0.87 \\
(0.75) \\
{[1.15]} \\
\text { OLS } \\
\end{array}$ & $\begin{array}{c}-1.08^{* *} \\
(0.46) \\
{[-2.32]} \\
\text { OLS } \\
\end{array}$ & $\begin{array}{c}-0.02 \\
(0.62) \\
{[-0.04]} \\
\text { OLS } \\
\end{array}$ & $\begin{array}{c}0.14^{* *} \\
(0.07) \\
{[1.84]} \\
\text { Ordered Logit }\end{array}$ & $\begin{array}{c}-0.02 \\
(0.06) \\
{[-0.30]} \\
\text { Ordered Logit }\end{array}$ \\
\hline Net migration & $\begin{array}{c}-0.21 \\
(0.13) \\
{[-1.56]}\end{array}$ & $\begin{array}{c}-0.16 \\
(0.13) \\
{[-1.29]}\end{array}$ & $\begin{array}{c}-0.11 \\
(0.14) \\
{[-0.80]}\end{array}$ & $\begin{array}{c}-0.22 \\
(0.18) \\
{[-1.18]}\end{array}$ & $\begin{array}{c}-0.11 \\
(0.18) \\
{[-0.62]}\end{array}$ & $\begin{array}{c}-0.31 \\
(0.26) \\
{[-1.19]}\end{array}$ & $\begin{array}{c}-0.03 \\
(0.03) \\
{[-1.08]}\end{array}$ & $\begin{array}{c}-0.05^{*} \\
(0.03) \\
{[-1.58]}\end{array}$ \\
\hline Urbanization & $\begin{array}{r}0.26^{* *} \\
(0.12) \\
{[2.11]}\end{array}$ & $\begin{array}{l}0.11 \\
(0.10) \\
{[1.01]}\end{array}$ & $\begin{array}{l}0.05 \\
(0.10) \\
{[0.48]}\end{array}$ & $\begin{array}{l}0.21 \\
(0.22) \\
{[0.97]}\end{array}$ & $\begin{array}{l}0.12 \\
(0.18) \\
{[0.66]}\end{array}$ & $\begin{array}{l}0.35 \\
(0.22) \\
{[1.61]}\end{array}$ & $\begin{array}{l}0.04 \\
(0.03) \\
{[1.38]}\end{array}$ & $\begin{array}{l}0.05^{*} \\
(0.03) \\
{[1.85]}\end{array}$ \\
\hline
\end{tabular}


Table 2. Continued.

\begin{tabular}{|c|c|c|c|c|c|c|c|c|}
\hline $\begin{array}{l}\text { Dependent Variable } \\
\text { Model Estimated }\end{array}$ & $\begin{array}{l}\text { AKP Vote } \\
2002 \\
\text { OLS }\end{array}$ & $\begin{array}{c}\text { AKP Vote } \\
2007 \\
\text { OLS }\end{array}$ & $\begin{array}{c}\text { AKP Vote } \\
2011 \\
\text { OLS }\end{array}$ & $\begin{array}{l}\text { AKP Seat } \\
2002 \\
\text { OLS }\end{array}$ & $\begin{array}{c}\text { AKP Seat } 2007 \\
\text { OLS }\end{array}$ & $\begin{array}{c}\text { AKP Seat } \\
2011 \\
\text { OLS }\end{array}$ & $\begin{array}{l}\text { AKP Wins } \\
\text { Ordered Logit }\end{array}$ & $\begin{array}{l}\text { AKP Seat 50P } \\
\text { Ordered Logit }\end{array}$ \\
\hline Electoral Disproportionality & & & & $\begin{array}{r}0.66^{* *} \\
(0.33) \\
{[2.02]}\end{array}$ & $\begin{array}{c}0.89^{* * * *} \\
(0.31) \\
{[2.84]}\end{array}$ & $\begin{array}{l}0.84^{* *} \\
(0.35) \\
{[2.37]}\end{array}$ & & $\begin{array}{l}0.04 \\
(0.04) \\
{[1.14]}\end{array}$ \\
\hline Constant & $\begin{array}{c}-15.86 \\
(14.55) \\
{[-1.09]}\end{array}$ & $\begin{array}{c}50.04^{* * *} \\
(13.94) \\
{[3.59]}\end{array}$ & $\begin{array}{c}28.89^{* *} \\
(13.76) \\
{[2.10]}\end{array}$ & $\begin{array}{l}-9.98 \\
(33.04) \\
{[-0.30]}\end{array}$ & $\begin{array}{c}50.62^{* *} \\
(25.49) \\
{[1.99]}\end{array}$ & $\begin{array}{c}0.59 \\
(32.03) \\
{[0.02]}\end{array}$ & & \\
\hline Adjusted/Pseudo $\mathrm{R}^{2}$ & 0.42 & 0.48 & 0.48 & 0.45 & 0.49 & 0.48 & 0.27 & 0.16 \\
\hline Chi-Squares & $109.20^{* * *}$ & $106.00^{* * *}$ & $111.60^{* * *}$ & $80.10^{* * *}$ & $113.70^{* * *}$ & $98.40^{* * *}$ & $40.48^{* * *}$ & $28.99^{* * *}$ \\
\hline$N$ & 81 & 81 & 81 & 81 & 81 & 81 & 81 & 81 \\
\hline
\end{tabular}

Note: Cell entries are coefficients, robust standard errors in parentheses, and $t$-scores in square brackets. Adjusted R-Squares for the OLS models and Pseudo R-Squares for the ordered logit models. ${ }^{*} p<.10$; ${ }^{* *} p<.05 ;{ }^{* * *} p<.01$. All of the models are significant at 1\% level. Sources: Turkish Electoral Council (YSK), Tezcür (2012), Turkish Statistical Institute (TÜiK), Social Security Institution (SGK). AKP Wins (between 0-3): It shows the number of national elections in which the AKP was the first party in each province. AKP Seat 50P (between 0-3): It shows the number of national elections in which the AKP succeeded to exceed $50 \%$ seat threshold in each province. Secondary Education: Percent of population with secondary education and higher. Preacher School Enrolment: Pupils enrolled to preacher schools per 1000 people adjusted for province population. Basic Health Services: Physicians per 10,000 people. Basic Infrastructure Services: Percent of Population with Sewage Services. Unemployment: Unemployment rate at the province level. Population out of Social Security: Percent of population out of social security in each province. Net migration: Positive when a province receives migrants from other provinces; and negative if there are higher figure of outmigration in a province. Electoral Disproportionality: Gallagher index (1991). 
Furthermore, the change of the impact of the religiosity indicator is positive over time. In other words, religiosity has greater effect on the AKP support over individual elections. This is evident in the increasing coefficients and $t$-scores of the religiosity variable over the 2002 to 2011 elections, both for the vote and seat shares.

The OLS analyses of both AKP vote and seat shares show that religiosity has greater impact on the AKP support levels over individual elections. To be more specific, one standard deviation increase of the religiosity variable (that is, 0.37 units increase; refer to Appendix 1) would lead to 5.3, 5.9, and 6.5\% increase in AKP vote shares in the 2002, 2007, and 2011 elections, and 8.3, 9.2, and 10.1\% increase in AKP seat shares in the 2002, 2007, and 2011 elections, respectively.

The cross-sectional analyses of the religiosity variable support the longitudinal findings about the effect of religiosity for the rising AKP hegemony. Religiosity indicator is very significant both for the "AKP Wins" and the "AKP Seat 50P" variables. In fact, it is again the strongest of all independent variables (in light of the $t$-scores). Interpretations of these ordered logit models shed further insights. Based on Clarify, an increase in preacher school enrolment from its mean observed value (for example, Uşak, Balıkesir provinces) to its maximum value (Giresun province) increases the probability of an AKP electoral hegemony (that is, AKP Win = 3) by $22.7 \%$ and the probability of an AKP seat hegemony (that is, AKP Seat $50 \mathrm{P}=3$ ) by $37.2 \%$. Both longitudinal OLS analyses of individual elections and cross-sectional ordered logit analyses of the ordinal hegemony variables prove that religiosity is the strongest determinant of the AKP's emerging hegemony in Turkey. This leads to two major findings. First, contrary to the AKP leadership's efforts to present their party as a "service-oriented party" and findings at the individual level (based on surveys), religious ideology stands as the primary determinant of the AKP support at the local level. Second, this finding also buttresses the fact that AKP heavily politicizes the secular-religious cleavage in Turkey by polarizing the divisions between the secularists and Islamists and rallying religiously conservative voters under its banner.

To this end, the AKP case contrasts with some cases of hegemonic parties throughout the world, such as Kuomintang in Taiwan, United Russia in Russia, while showing close similarities to others, such as the National Front in Malaysia, in that AKP as a hegemony-aspiring party has utilized a social-cleavage-centred electoral strategy (articulating the secular-religious cleavage for the AKP case), instead of a catch-all strategy with shallow ideological orientations and broader electoral appeals to different segments of the society. ${ }^{44}$ Both Turkey's societal dynamics and the party's political organization and ideological orientation have played a role on why the AKP has chosen the former path, but not the latter.

Provision of better public infrastructure services is also positively and strongly correlated with the AKP's electoral success. The linkage between the provision of basic infrastructure services and the AKP vote shares gets stronger over elections in 2002 to 2011 , which is evidenced by increasing coefficients and $t$-scores. This is an interesting finding; yet, it is hard to define this relationship as a causal one based on this statistical finding per se. However, scholarly evidence by other experts regarding the partisan bias of the distribution of goods and services furthers our conviction that pork-barrel politics plays a role in the AKP case. For instance, Buğra and Candaş pinpoint the fact that the in-kind assistance distributed to the poor by the Social Solidarity Foundation dramatically increased in quantity (in fact it tripled) before the 2009 municipal elections. The social security services were primarily targeted at the "Eastern towns where [religiously] 
conservative parties have historically had little chance in elections". 45 The Turkish Electoral Council (YSK) intervened to stop the distribution of "in-kind assistance" in these provinces, stating that this would hinder the fairness of elections. However, the decision of the Council was not heeded by the provincial governor. Moreover, Erdoğan defended the governor by stating that "Charity is legitimate in our culture". This incident supports the fact that the provision of basic infrastructure services is done with a partisan bias.

Ordered logit regressions also confirm this point. Both ordered logit regressions yield statistically significant coefficient for the infrastructure variable. Furthermore, Clarify simulations indicate that an increase in provision of basic infrastructure services from its minimum observed value (in Hakkari province, 23\%) to 50\% increases the probability of an AKP electoral hegemony (that is, AKP Win = 3) by $17.5 \%$ and an AKP seat hegemony (that is, AKP Seat $50 \mathrm{P}=3$ ) by $8.5 \%$. Improved infrastructure that results from better public policy outputs yields higher probability of the AKP hegemony. This is clearly indicative of pork barrel politics in Turkish politics (beyond the "need-based" provision of public services) and its linkage to the AKP's rising hegemony. These results support hypothesis 2 related to the importance of pork barrel politics in emerging hegemonies.

The comparison between the effects of health vs. infrastructure expenditures on the AKP's growing hegemony is interesting insofar as the health variable has a significant impact in none of the regressions, while the infrastructure variable is clearly linked to AKP support in all of them. What is the reason behind this stark difference when both measures might reasonably be taken as clientelist mechanisms of support buying? A possible explanation is that sectors such as infrastructure lend themselves more readily to use as patronage because of the large sums of money involved. For example, according to 2014 budgetary statistics in Turkey, infrastructure expenditures (such as building of roads, bridges, hospitals, sewage management services, and the like) account for 3.8\% of the country's GDP (gross domestic product) and $15.3 \%$ of its national budget (and these figures were similar in previous years). It is easy to see how such sums of money can become a profitable source of patronage for the ruling party. In contrast, health expenditures (for example, purchase of medical equipment, local clinical expenditures) constitute only $1.2 \%$ of Turkey's GDP and $4.8 \%$ of its overall budget. Compared to infrastructure, health expenditures would not seem to be sizeable enough to be an effective patronage tool in the eyes of the ruling party. Overall, as the Turkish case suggests, infrastructure expenditures would seem to have been perceived by the AKP both as a tool of patronage, as well as pork barrel politics (as a mechanism to reward loyal localities and punish opposition), while health service expenditures have not been seen as serving the same purpose.

Evidence of "economic voting" can also be found in the statistical analyses. Longitudinal analyses of individual elections show that both unemployment and percentage of province population out of social security negatively correlate with the AKP vote and seat shares. The impact of unemployment has risen statistically from the 2002 election to the succeeding elections, as evidenced by increased coefficients and $t$-scores. A one unit increase in the percentage of the unemployed caused a $1.8 \%$ decrease in AKP vote shares and $2.8 \%$ decrease in AKP seat shares in the most recent 2011 election. In a similar vein, the effect of the percentage of population out of social security increases over time, as evidenced by its ascending impact on AKP seat share regressions. 
A one unit increase in this figure led to 1.6\% decrease in AKP seat shares in the 2007 election and $1.8 \%$ decrease in AKP seat shares in the 2011 election.

Furthermore, ordered logit regressions show that unemployment at the locality level hinders the occurrence of AKP's electoral hegemony (“AKP Wins"). Simulations show that a $5 \%$ increase in the percentage of the unemployment in a province (from $5 \%$ to $10 \%$ ) decreases the probability of the AKP electoral hegemony (that is, AKP Win = 3 ) by $27.2 \%$. These results confirm that, contrary to established hegemonies, emerging hegemonies are affected by economic slumps. Hypothesis 3 regarding economic voting holds in light of these results. Voters reward the governing party for better services and punish them due to bad economic outcomes. Localities with better provision of public services and lower levels of unemployment are more likely to produce a strong electoral hegemony, as evidenced by the AKP case.

Electoral disproportionality, measured by the Gallagher (1991), very strongly and positively predicts AKP seat shares, in line with Hypothesis 4. The mean score of the Gallagher index for the three elections under consideration is $22.3 \%$. A one unit increase in this index (that is, even higher disproportionality) would have led to $0.6 \%$ increase in the AKP seat shares in the 2002 election, and $0.8 \%$ increase in the AKP seat shares in the 2007 and 2011 elections. This shows that higher figures of electoral disproportionality at the province level have led to higher AKP seats, even after controlling for socioeconomic and demographic measures. However, electoral disproportionality loses its statistical significance in the ordered logit regression for seat hegemony (AKP Seat 50P). This shows us that electoral institutions can prove pivotal in seat distributions; yet, they should be tested for their significance in light of other control variables to see whether they are crucial to create seat hegemony.

Demographic factors also matter for the AKP hegemony, but not as strongly as ideology, pork barrel politics, economic voting, and electoral disproportionality. The median age of a locality is negatively correlated with the 2007 election (that is, localities with higher percentage of younger citizens supported the AKP more during this particular election). Yet, cross-sectional analysis of median age, based on the ordered logit regression for the "AKP Wins" variable, show that this pattern is reversed when we take into account the overall trend of this variable. In other words, the ordered logit regression for median age shows that a decrease in median age in a province from its mean value (30.71) to 25 (for example, Bingöl, Gaziantep provinces) decreases the probability of the AKP electoral hegemony by $16.1 \%$. On the other hand, Clarify simulations indicate that an increase in median age in a province from 30 to 35 (for example, Amasya, Çankırı) increases the probability of the AKP electoral hegemony by $10.3 \%$. Overall, provinces with younger populace are highly likely to yield lower probability of AKP hegemony, whereas localities with higher percentage of the elderly are causally linked to the AKP hegemony.

Net migration is not significant in the vote and seat share outcomes of the individual elections. However, it negatively affects the occurrence of the AKP seat hegemony (though not very strongly). Simulations indicate that a decrease in net migration from zero to -10 (a province with outmigration such as Erzincan and Tokat in Eastern and Central Anatolia) increases the probability of the AKP seat hegemony (that is, AKP Seat $50 \mathrm{P}=3$ ) by $12.1 \%$. This is indicative of the fact that the transformation of the demographic change from rural areas to urban centres has not yet been finalized and localities with outmigration still constitute at least some part of the AKP hegemony. 
Urbanization is only significant for the 2002 election, in which higher urbanization yielded higher AKP vote shares. Moreover, urbanization is related to the occurrence of the AKP seat hegemony, in light of the ordered logit regression for the "AKP Seat 50P" variable. Simulations show that an increase in urbanization from its mean value $(65 \%)$ to $85 \%$ (for example, Kayseri province) increases the probability of the AKP seat hegemony (that is, AKP Seat $50 \mathrm{P}=3$ ) by $19.7 \%$. However, like the net migration variable, the urbanization variable is barely significant among all independent variables.

Overall, religious ideology, pork barrel politics, economic voting, and electoral institutions are all strong determinants of the AKP's rising hegemony. Both the OLS and ordered logit regressions validate this important finding. Demographic variables do not explain the AKP hegemony as strongly as the previous indicators but they still shed some light on the occurrence of the AKP hegemony.

\section{Concluding remarks: 2015 national elections and beyond}

Turkey had an election on 7 June 2015. AKP lost its parliamentary majority for the first time in its history and is now looking for a coalition partner. How does this relate to the article's major argument regarding the AKP's emerging hegemony? In fact, AKP's vote share $(41 \%)$ and seat share (47\%) still make the party the first and the strongest party in Turkish politics (its closest rival, CHP got $25 \%$ of the votes). The party will either choose to be the bigger coalition partner or its leadership may pursue a snap election to return the party to its undisputedly dominant position. The major difference between the 2015 election and the previous one in 2011 was that the pro-Kurdish BDP (newly named as Peoples' Democratic Party, HDP) decided to enter the election as a party (instead of running as independent candidates to counteract the aforementioned $10 \%$ threshold, its former tactic) with a broader appeal to leftist votes throughout Turkey. The party indeed succeeded to surpass the gargantuan $10 \%$ threshold by getting $13 \%$ of the votes, thanks to not only the Kurdish votes (it performed amazingly well in Eastern and Southeastern Anatolia predominantly populated by the Kurds), but also the party's increased vote share in major metropolitan cities including Istanbul, Izmir, and the like. This supports the article's discussion of electoral disproportionality. Furthermore, it would be too early to conclude that the AKP's emerging hegemony has come to a halt. We still do not know whether this will be reversed or not. Time will show whether AKP will succeed to turn its aspirant hegemony into a consolidated one or whether it will fail to do so.

All in all, this article has shown that party hegemony can only emerge through a collection of individual-level (albeit aggregated), lower-level structural, and macro-level institutional factors. To this end, this research introduces a novel approach to the study of hegemonic parties as it examines an emerging electoral hegemony by focusing on in-depth analyses at the local level. Behavioural approaches that stress the usage of individual-level data (surveys, questionnaires and the like) and systemic approaches that analyse nation-wide factors are surely beneficial to understand the political, socioeconomic, and demographic forces behind political party support in general and hegemonic party support specifically. However, these should be buttressed with thorough sub-systemic, local-level analyses. Insights from local-level analyses are indispensable both for the theory and the empirics of hegemonic party support. With this in mind, this paper has sought to incorporate individual-level, lower-level structural, and macro-level institutional factors to understand party hegemony. The replicable 
nature of the dataset enables further testing of these findings in comparable cases for generalizability.

\section{Disclosure statement}

No potential conflict of interest was reported by the authors.

\section{Notes}

1. Schedler, "What is Democratic Consolidation?"

2. Pempel, Uncommon Democracies, 4.

3. Ibid.

4. Sartori, Parties and Party Systems.

5. Magaloni, Voting for Autocracy, 33.

6. See for instance, Diaz-Cayeros et al., "Tragic Brilliance"; Magaloni, Voting for Autocracy; Kitschelt and Wilkinson, Patrons, Clients, and Policies; Lust-Okar, "Legislative Elections in Hegemonic Authoritarian Regimes"; Smyth et al., "Engineering Victory"; Hadenius and Teorell, "Pathways from Authoritarianism"; Suryadinata, "The Decline of the Hegemonic Party"; Magaloni and Kricheli, "Political Order"; Reuter and Gandhi, "Economic Performance and Elite Defection".

7. Bader, "Hegemonic Political Parties in Post-Soviet Eurasia."

8. Trounstine, "All Politics is Local," 612.

9. Gibson and Suarez-Cao, "Federalized Party Systems."

10. Grigoriadis, "Islam and Democratization in Turkey"; Ocakli, "Political Entrepreneurs, Clientelism, and Civil Society in Turkey"; Ocakli, "Notable Networks."

11. Kirdis, "Immoderation"; Somer, "Moderation of Religious and Secular Politics"; Tepe, "The Perils of Polarization."

12. Radikal, Separation of Powers is an Impediment [Kuvvetler Ayrilığı Engel] December 18, 2012.

13. Gunther and Diamond, "Species of Political Parties."

14. Ibid., 171.

15. Hürriyet, The Parliament Vice-Chair Yakut: Mixed-gender Education is a Great Mistake [TBMM Başkanvekili Yakut: Kızh erkekli eğitim büyük bir yanlış] November 21, 2013.

16. Öniş, "Sharing Power"; Cinar and Ugur Cinar, "Building Democracy to Last."

17. Özbudun, "AKP at the Crossroads," 1.

18. Müftüler-Baç and Keyman, "Turkey under the AKP," 86;see also Keyman and Gümüşçü, Democracy, Identity and Foreign Policy in Turkey.

19. Çarkoğlu, "Economic Evaluations vs. Ideology."

20. The remaining portions are as follows: $3 \%$ of the AKP voters state that there is no "viable political alternative." The remaining $5 \%$ chose not to respond to this question.

21. Kalaycıoğlu, "Politics of Conservatism," 230.

22. Çarkoğlu, "Economic Evaluations vs. Ideology," 319.

23. World Bank, 2013.

24. $43 \%$ of the CHP electorate and $49 \%$ of the MHP electorate hold degrees lower than secondary education.

25. Downs, An Economic Theory of Democracy; Kitschelt, "Party Systems." Converse (1964) defines "ideology" as a "configuration of ideas and attitudes in which the elements are bound together by some form of constraint or functional interdependence."

26. Magaloni, Voting for Autocracy, 15.

27. Keyman and Gümüş̧̧ü, Democracy, Identity and Foreign Policy, 128.

28. On the rise of political Islam in the Middle East, see for instance, Tessler, "Religion, Religiosity and the Place of Islam"; Schwedler, "Religion and Politics"; Masoud, "Islamist Parties."

29. Güneş-Ayata and Ayata, "Ethnic and Religious Bases of Voting," 148-150.

30. Magaloni, Voting for Autocracy.

31. Suryadinata, "The Decline of the Hegemonic Party."

32. Diaz-Cayeros et al., "Tragic Brilliance."

33. Garner and Garner, "Problems of the Hegemonic Party," 258. 
34. Magaloni, Voting for Autocracy, 123.

35. Kitschelt and Wilkinson, Patrons, Clients, and Policies, 2.

36. Reuter and Gandhi, "Economic Performance and Elite Defection."

37. Poterba, "Demographic Change."

38. Jennings, "Residues of a Movement."

39. Kitschelt and Wilkinson, Patrons, Clients, and Policies, 35.

40. Auyero, "The Logic of Clientelism"; Stokes, "Perverse Accountability."

41. Kitschelt and Wilkinson, Patrons, Clients, and Policies, 2.

42. Carey and Hix, "The Electoral Sweet Spot." See also Powell and Vanberg, "Election Laws."

43. All explanatory variables are set to their mean values for reference (by "setx mean" command).

44. White, "Dominant Party Systems"; Wong et al., "Malaysia."

45. Buğra and Candaş, "Change and Continuity under an Eclectic Social Security Regime," 523.

\section{Notes on contributor}

Kursat Cinar earned his $\mathrm{PhD}$ in Political Science from Ohio State University. His research interests centre on party politics, democratization, patron-client relationships, and development. He is a Fulbright Alumnus (thanks to his MA in Economics from New York University). He has published in Political Studies, Contemporary Politics, Mediterranean Politics, Journal of Balkan and Near Eastern Studies, and Turkish Studies. He is the recipient of the 2013 Sabanci International Research Award. He works at Bilkent University, Ankara, Turkey.

\section{Bibliography}

Auyero, J. "The Logic of Clientelism in Argentina: An Ethnographic Account." Latin American Research Review 35, no. 3 (2000): 55-81.

Bader, M. "Hegemonic Political Parties in Post-Soviet Eurasia: Towards Party-Based Authoritarianism?" Communist and Post-Communist Studies 44, no. 3 (2011): 189-197.

Buğra, A., and Candaş, A. "Change and Continuity under an Eclectic Social Security Regime: The Case of Turkey." Middle Eastern Studies 47, no. 3 (2011): 515-528.

Carey, J. M., and S. Hix. "The Electoral Sweet Spot: Low-Magnitude Proportional Electoral Systems." American Journal of Political Science 55, no. 2 (2011): 383-397.

Çarkoğlu, A. "Economic Evaluations vs. Ideology: Diagnosing the Sources of Electoral Change in Turkey, 2002-2011.” Electoral Studies 31, no. 3 (2012): 513-521.

Cinar, K., and M. Ugur Cinar. "Building Democracy to Last: The Turkish Experience in Comparative Perspective." Mediterranean Politics (2015). doi:10.1080/13629395.2015.1042246.

Converse, P. E. “The Nature of Belief Systems in Mass Publics." In Ideology and Discontent, edited by David Apter, 206-261. New York: The Free Press of Glencoe, 1964.

Diaz-Cayeros, A., B. Magaloni, and B. R. Weingast. "Tragic Brilliance: Equilibrium Hegemony and Democratization in Mexico." 2003. http://www.stanford.edu/ albertod/tragicbrilliance.pdf.

Downs, A. An Economic Theory of Democracy. New York: Harper \& Row, 1957.

Gallagher, M. "Proportionality, Disproportionality and Electoral Systems." Electoral Studies 10 (1991): 33-51.

Garner, L., and R. Garner. "Problems of the Hegemonic Party: The PCI and the Structural Limits of Reform." Science \& Society 45, no. 3 (1981): 257-273.

Gibson, E. L., and J. Suarez-Cao. "Federalized Party Systems and Subnational Party Competition: Theory and an Empirical Application to Argentina." Comparative Politics 43, no. 1 (2010): 21-39.

Grigoriadis, I. "Islam and Democratization in Turkey: Secularism and Trust in a Divided Society." Democratization, 16, no. 6 (2009): 1194-1213.

Güneş-Ayata, A., and S. Ayata. "Ethnic and Religious Bases of Voting." In Politics, Parties and Elections in Turkey, edited by Y. Esmer and S. Sayarn, 137-156. Boulder, CO: Lynn Rienner, 2002.

Gunther, R., and L. Diamond. "Species of Political Parties: A New Typology." Party Politics, 9, no. 2 (2003): 167-199.

Hadenius, A., and J. Teorell. “Pathways from Authoritarianism." Journal of Democracy 18, no. 1 (2007): 143-157. 
Jennings, M. K. "Residues of a Movement: The Aging of the American Protest Generation." The American Political Science Review 81, no. 2 (1987): 367-382.

Kalaycıoğlu, E. "Politics of Conservatism in Turkey." Turkish Studies 8, no. 2 (2007): 233-252.

Keyman, F., and Ş. Gümüşçü. Democracy, Identity and Foreign Policy in Turkey: Hegemony through Transformation (Islam and Nationalism). New York: Palgrave MacMillan, 2014.

Kirdis, E. "Immoderation: Comparing the Christian Right in the US and Pro-Islamic Movement-parties in Turkey." Democratization (2015). doi:10.1080/13510347.2014.975125.

Kitschelt, H. "Party Systems." In The Oxford Handbook of Comparative Politics, edited by Carles Boix and Susan C. Stokes, 522-554. Oxford: Oxford University Press, 2009.

Kitschelt, H., and S. I. Wilkinson, eds. Patrons, Clients, and Policies: Patterns of Democratic Accountability and Political Competition. Cambridge, UK: Cambridge University Press, 2007.

Lust-Okar, E. "Legislative Elections in Hegemonic Authoritarian Regimes." In Democratization by Election: A New Mode of Transition, edited by Staffan I. Lindberg, 226-245. Baltimore, MD: Johns Hopkins University Press, 2009.

Magaloni, B. Voting for Autocracy: Hegemonic Party Survival and its Demise in Mexico. New York, NY: Cambridge University Press, 2006.

Magaloni, B., and R. Kricheli. "Political Order and One-Party Rule." Annual Review of Political Science 13, no. 1 (2010): 123-143.

Masoud, T. "Islamist Parties: Are They Democrats? Does it Matter?" Journal of Democracy 19, no. 3 (2008): 19-24.

Müftüler-Baç, M., and Keyman, F. "Turkey under the AKP: The Era of Dominant-Party Politics." Journal of Democracy 23, no. 1 (2012): 85-99.

Ocakli, F. "Notable Networks: Elite Recruitment, Organizational Cohesiveness, and Islamist Electoral Success in Turkey.” Politics \& Society (2015). doi:10.1177/0032329215584790.

Ocakli, F. "Political Entrepreneurs, Clientelism, and Civil Society: Supply-side Politics in Turkey." Democratization, (2015). doi:10.1080/13510347.2015.1013467.

Öniş, Z. "Sharing Power: Turkey's Democratization Challenge in the Age of the AKP Hegemony." Insight Turkey 15, no. 2 (2013): 103-122.

Özbudun, E. "AKP at the Crossroads: Erdoğan's Majoritarian Drift." South European Society and Politics 19, no. 2 (2014): 1-13.

Pempel, T. J. Uncommon Democracies: The One-Party Dominant Regimes. Ithaca and London: Cornell University Press, 1990.

Poterba, J. M. "Demographic Change, Intergenerational Linkages, and Public Education." The American Economic Review 88, no. 2 (1998): 315-320.

Powell, Jr., G. B., and G. S. Vanberg. "Election Laws, Disproportionality and Median Correspondence: Implications for Two Visions of Democracy.” British Journal of Political Science 30, no. 3 (2000): 383-411.

Reuter, O. J., and J. Gandhi. "Economic Performance and Elite Defection from Hegemonic Parties." British Journal of Political Science 41, no. 1 (2011): 83-110.

Sartori, G. Parties and Party Systems: A Framework for Analysis. Cambridge: Cambridge University Press, 1976.

Schedler, Andreas. “What is Democratic Consolidation?” Journal of Democracy 9, no. 2 (1998): 91-107.

Schwedler, J. "Religion and Politics." In Politics and Society in the Contemporary Middle East, edited by M. P. Angrist, 111-132. Boulder, CO: Lynne Rienner, 2010.

Smyth, R., A. Lowry, and B. Wilkening. "Engineering Victory: Institutional Reform, Informal Institutions, and the Formation of a Hegemonic Party Regime in the Russian Federation." PostSoviet Affairs 23, no. 2 (2007): 118-137.

Somer, M. "Moderation of Religious and Secular Politics, a Country's 'Centre' and Democratization." Democratization 21, no. 2 (2014): 244-267.

Stokes, S. "Perverse Accountability: A Formal Model of Machine Politics with Evidence from Argentina." American Political Science Review 99, no. 3 (2005): 315-325.

Suryadinata, L. "The Decline of the Hegemonic Party System in Indonesia: Golkar after the Fall of Suharto." Contemporary Southeast Asia 29, no. 2 (2007): 333-358.

Tepe, S. "The Perils of Polarization and Religious Parties: The Democratic Challenges of Political Fragmentation in Israel and Turkey." Democratization 20, no. 5 (2013): 831-856.

Tessler, M. "Religion, Religiosity and the Place of Islam in Political Life: Insights from the Arab Barometer Surveys." Middle East Law and Governance 2, no. 2 (2010): 221-252. 
Tezcür, G. M. Turkish Elections at Province Level (TEPL) Dataset. 2012. www.luc.edu/faculty/gtezcur/ data.html.

Tomz, M., J. Wittenberg, and G. King. "Clarify: Software for Interpreting and Presenting Statistical Results." Journal of Statistical Software 8, no. 1 (2003): 1-29.

Trounstine, J. "All Politics is Local: The Reemergence of the Study of City Politics." Perspectives on Politics 7, no. 3 (2009): 611-618.

White, D. "Dominant Party Systems: A Framework for Conceptualizing Opposition Strategies in Russia." Democratization 18, no. 3 (2011): 655-681.

Wong, C., J. Chin, and N. Othman. "Malaysia-Towards a Topology of an Electoral One-Party State." Democratization 17, no. 5 (2010): 920-949.

\section{Appendix 1}

Descriptive statistics

\begin{tabular}{|c|c|c|c|c|c|}
\hline & Mean & Median & Minimum & Maximum & Standard Deviation \\
\hline \multicolumn{6}{|l|}{ Dependent Variables } \\
\hline AKP Vote 2002 & 32.68 & 32.46 & 6.50 & 54.94 & 13.40 \\
\hline AKP Vote 2007 & 47.88 & 48.78 & 12.27 & 71.12 & 12.60 \\
\hline AKP Vote 2011 & 50.85 & 52.19 & 15.75 & 69.64 & 13.19 \\
\hline AKP Seat 2002 & 68.25 & 66.67 & 0 & 100.00 & 22.71 \\
\hline AKP Seat 2007 & 65.39 & 66.67 & 0 & 100.00 & 20.15 \\
\hline AKP Seat 2011 & 63.12 & 66.67 & 0 & 100.00 & 23.34 \\
\hline AKP Wins & 2.35 & 3 & 0 & 3 & 1.08 \\
\hline AKP Seat 50P & 2.04 & 3 & 0 & 3 & 1.24 \\
\hline \multicolumn{6}{|l|}{ Independent Variables } \\
\hline \multicolumn{6}{|l|}{ Political Variables } \\
\hline Electoral Disproportionality & 22.34 & 21.15 & 10.16 & 40.21 & 6.94 \\
\hline \multicolumn{6}{|l|}{ Socioeconomic Variables } \\
\hline Secondary Education & 34.11 & 34.96 & 10.14 & 63.59 & 8.07 \\
\hline Preacher School Enrolment & 0.90 & 0.84 & 0 & 2.11 & 0.37 \\
\hline Basic Health Services & 14.54 & 13.30 & 9.04 & 30.62 & 4.15 \\
\hline Basic Infrastructure Services & 85.02 & 90.00 & 23.00 & 100.00 & 13.46 \\
\hline Unemployment & 7.76 & 7.28 & 3.46 & 15.28 & 2.41 \\
\hline Pop.n out of Social Security & 2.65 & 1.91 & 0.24 & 10.67 & 2.32 \\
\hline \multicolumn{6}{|l|}{ Demographic Variables } \\
\hline Median Age & 30.17 & 31.60 & 18.50 & 37.50 & 5.26 \\
\hline Net migration & -5.04 & -5.44 & -46.67 & 16.58 & 9.59 \\
\hline Urbanization & 65.16 & 64.05 & 35.18 & 98.96 & 13.51 \\
\hline
\end{tabular}

Note: Observation numbers for all longitudinal variables $=243$; cross-sectional variables $=81$. Sources for all variables are shown in Table 2. 
Appendix 2 Correlation Matrix - Independent Variables

\begin{tabular}{|c|c|c|c|c|c|c|c|c|c|c|}
\hline & Sec.Educ'n & Preach_Enr & Health & Infrastr & Unemp & Pop_Out_Soc & Age & Net_Migrat.n & Urban. & Elec.Disp. \\
\hline Secondary Education & 1.00 & & & & & & & & & \\
\hline Preacher School Enrolment & -0.32 & 1.00 & & & & & & & & \\
\hline Basic Health Services & 0.40 & -0.03 & 1.00 & & & & & & & \\
\hline Basic Infrastructure Services & 0.20 & -0.01 & 0.29 & 1.00 & & & & & & \\
\hline Unemployment & 0.12 & 0.03 & -0.11 & -0.15 & 1.00 & & & & & \\
\hline Population out of Social Security & -0.03 & 0.05 & -0.06 & -0.11 & 0.02 & 1.00 & & & & \\
\hline Median Age & 0.35 & -0.17 & 0.33 & 0.29 & -0.56 & -0.14 & 1.00 & & & \\
\hline Net Migration & 0.44 & -0.20 & 0.25 & 0.14 & -0.01 & -0.11 & 0.34 & 1.00 & & \\
\hline Urbanization & 0.48 & -0.14 & 0.45 & 0.42 & 0.18 & -0.17 & 0.12 & 0.43 & 1.00 & \\
\hline Electoral Disproportionality & -0.06 & -0.02 & -0.25 & -0.03 & 0.10 & 0.06 & -0.17 & -0.21 & -0.31 & 1.00 \\
\hline
\end{tabular}

